\title{
Analisis Penggunaan Internet Sebagai Referensi Mahasiswa Stain Curup (Studi Manfaat dan Dampak Media Massa)
}

\author{
Bakti Komalasari \\ STAIN CURUP \\ baktikomala@gmail.com \\ Adinda Tessa Naumi \\ STAIN Curup \\ adindatessa@gmail.com
}

This study is a study focused on finding meaning towards the behavior of internet usage as reference of STAIN Curup students. In line with the concept of an active audience, this research would focus on the internet as a mass media. With the advancement of information technology and mass media, providing various facilities in accessing information especially through the internet. STAIN Curup students are required to keep updating their knowledge and information especially with regard to their studies. This need is what makes the student must continue to add the supporting reference study. In addition to books, print journals and modules, the internet becomes one of the reference sources used by students. Therefore, it needs to be studied further about how the use of internet as a reference STAIN Curup students? how is the impact of internet use as a reference of STAIN Curup students?

To answer the problems, this research uses the uses and gratifications theory and the moderate effect model, which is expected to give meaning and peel the phenomenon of internet usage on the students. In line with the uses and gratifications theory, satisfaction will arise if needs are met. In this case, the satisfaction of internet usage as reference of student is seen from the functioning of mass media, among others: information function, entertainment function, persuasion function, cultural transmission function and social inheritance, correlation function (linking). While the impact of internet use as a reference of students, among others, cognitive impact, affective impact, and behavioral impact. The impact of internet usage is also supported by individual factors; such as selective attention, selective perception, and selective retention, motivation and knowledge, beliefs, opinions, values, and needs, persuasion, personality and adjustment. And social factors, among others; age, sex, education and training, occupation and income, religion, residence.

Keywords: Internet, Uses And Gratifications Theory, Moderate Effect Theory

\begin{abstract}
Abstrak
Penelitian ini merupakan kajian yang difokuskan untuk mencari makna terhadap perilaku penggunaan internet sebagai referensi mahasiswa STAIN Curup. Sejalan dengankonsep khalayak aktif, penelitian ini akan terfokus pada internet sebagai media massa.Seiring kemajuan teknologi informasi dan media massa, memberikan berbagai
\end{abstract}


kemudahan dalam mengakses informasi khususnya melalui internet. Mahasiswa STAIN Curup dituntut untuk terus mengupdate ilmu dan informasi khususnya berkenaan dengan studi mereka. Kebutuhan inilah yang membuat mahasiswa harus terus menambah referensi penunjang studi. Selain buku, jurnal cetak dan modul, internet menjadi salah satu sumber referensi yang digunakan oleh mahasiswa. Sehingga perlu dikaji lebih jauh mengenai bagaimana pemanfaatan internet sebagai referensi mahasiswa STAIN Curup? bagaimana dampak penggunaan internet sebagai referensi mahasiswa STAIN Curup?

Untuk menjawab permasalah, penelitian ini mengunakan uses and gratifications theory (teori kegunaan dan gratifikasi) serta model efek moderat, yang diharapkan dapat memberi makna dan mengupas fenomena penggunaan internet pada mahasiswa. Sejalan dengan uses and gratifications theory, kepuasan akan timbul jika kebutuhan terpenuhi. Dalam hal ini kepuasan penggunaan internet sebagai referensi mahasiswa dilihat dari berjalannya fungsi media massa, antara lain: fungsi informasi, fungsi hiburan, fungsi persuasi, fungsi transmisi budaya dan pewarisan sosial, fungsi korelasi (menghubungkan). Sedangkan dampak dari penggunaan internet sebagai referensi mahasiswa antara lain dampak kognitif, dampak afektif, dan dampak konatif/behavioral. Dampak/ efek penggunaan internet juga ditunjang oleh faktor individu; antara lain selective attention, selective perception, dan selective retention, motivasi dan pengetahuan, kepercayaan, pendapat, nilai, dan kebutuhan, pembujukan, kepribadian dan penyesuaian diri. Serta faktor sosial, antara lain; umur, jenis kelamin, pedidikan dan latihan, pekerjaan dan pendapatan, agama, tempat tinggal.

Kata Kunci: Internet, Uses And Gratifications Theory, Teori Efek Moderat

\section{Pendahuluan}

Kemajuan teknologi yang pesat, membawa dampak pada kemajuan teknologi komunikasi dan informasi. Saat ini istilah komunikasi bukanlah sesuatu yang asing di masyarakat. Dengan semakin pesatnya perkembangan media massa, istilah komunikasi massa menjadi begitu populer di masyarakat.

Avery dan McCain ${ }^{1}$ menungkapkan bahwa setiap aspek komunikasi massa adalah bermedia (mediated), dan interaksi bermedia berbeda dengan interaksi personal. Pertama, potensi masukan yang diindera penerima lebih terbatas. Kedua, penerima pesan bermedia mempunyai sedikit kontrol atau tidak mempunyai kontrol sama sekali atas sumber-sumbernya, yakni, umpan baliknya sangat terbatas. Akhirnya sumber-sumber pesan bermedia diketahui baik secara terbatas atau tidak diketahui sama sekali, hanya dibayangkan.

Menurut Wright ${ }^{2}$ dalam komunikasi massa khalayak relatif besar, heterogen dan anonim bagi sumber. Pengalaman bersifat publik dan cepat. Sumber bekerja lewat suatu organisasi yang rumit alih-alih dalam isolasi, dan pesan mungkin mewakili usaha banyak

${ }^{1}$ Stewart L. Tubbs dan Sylvia Moss, Human Communication: Konteks-Konteks Komunikasi.diterjemahkan oleh Deddy Mulyana dan Gembirasari, (Bandung: Remaja Rosdakarya, 2001), 198

${ }^{2}$ Tubbs , 199 
orang yang berbeda. Besarnya jumlah khalayak yang mampu dijangkau oleh komunikasi massa menjadi salah satu kekuatan komunikasi ini. Media massa seperti koran, buku, radio, dan televisi membantu memperbanyak, menduplikasi, atau memperkuat pesan untuk disebarkan kepada khalayak yang lebih besar ${ }^{3}$.

Jika dilihat dari prosesnya, secara garis besar ada dua proses dalam komunikasi massa, pertama, proses mengalirnya pesan, yaitu pada dasarnya merupakan proses satu arah. Kedua, proses seleksi, proses dua arah ${ }^{4}$. Proses pertama berlangsung ketika pesan mengalir dari komunikator ke khalayak, selanjutnya proses dimana khalayak menseleksi pesan yang masuk. Dalam hal ini, juga terjadi pemilihan penggunaan media massa yang sesuai dengan kebutuhan khalayak.

Awalnya studi menyatakan bahwa khalayak komunikasi massa dianggap pasif. Dengan pandangan model jarum hipodermik, dimana implikasinya adalah bahwa bila "injeksi" cukup kuat, ia akan mempengaruhhi penerima. Implikasi lebih jauh dari teori ini adalah bahwa media massa dapat menimbulkan pengaruh yang hampir bersifat menyihir, dan kadang-kadang berbahaya, terhadap khalayak. ${ }^{5}$ Akan tetapi perkembagan riset komunikasi mulai menunjukkan konsep yang berbeda tentang khalayak. Dewasa ini penerima komunikasi massa semakin dianggap sebagai khalayak aktif atau keras kepala. Schramm dan Roberts (1971) menungkapkan' ${ }^{6}$ :

"Suatu khalayak yang sangat aktif mencari apa yang mereka inginkan, menolak lebih banyak isi media dari pada menerimanya, berinteraksi dengan anggota-anggota kelompok yang mereka masuki dan dengan isi media yang mereka terima, dan sering menguji pesan media massa dengan membicarakannya dengan orang-orang lain atau membandingkannya dengan isi media lainnya."

Keaktifan khalayak dapat dilihat dari aktivitanya terhadap media massa. Jay G. Blumler $^{7}$ (1979) juga menawarkan beberapa saran jenis aktifitas khalayak yang dapat dilakukan oleh konsumen media. Termasuk di dalamnya kegunan, kesengajaan, selektivitas, dan kesulitan untuk memengaruhi.Pertama, media memiliki kegunaan bagi orang, dan orang menempatkan media pada kegunaan tersebut. Istilah ini disebut kegunaan (utility). Kesengajaan (intentionality) terjadi ketika motivasi orang menentukan konsumsi mereka akan isi media. Jenis ketiga dari aktivitas khalayak adalah istilah selektivitas (selectivity) yaitu bahwa khlayak menggunakan media dapat merefleksikan ketertarikan dan preferensi mereka. Akhirnya kesulitan untuk memengaruhi (imperviousness to influence) menyatakan bahwa khalayak membentuk pemahaman mereka sendiri dari isi dan bahwa makna memengaruhi apa yang mereka pikirkan dan lakukan. Mereka sering kali secara aktif menghindari jenis pengaruh media tertentu.

${ }^{3}$ Brent. D Ruben dan Lea P. Stewart, Komunikasi dan Perilaku Manusia, (Jakarta: Raja Grafindo Persada, 2013), 208

${ }^{4} J o s e p h$. A. Devito, Komunikasa Antarmanusia: Kuliah Dasar., terj. Agus Maulana, (Jakarta, Professional Books, 1997), 507

${ }^{5}$ Tubs, 207

${ }^{6}$ Tubs, 209

${ }^{7}$ Richard West dan Lynn H. Turner, Pengantar Teori Komunikasi: Analisis dan Aplikasi, (Jakarta: Salemba Humanika, 2008), 107 
Ada beberapa bentuk media komunikasi massa, antara lain surat kabar, majalah, tabloid, buku, radio, televisi, kaset/CD, film, internet, $\mathrm{dll}^{8}$. Internet sendiri merupakan media komunikasi yang bisa diterapkan dalam berbagai bentuk komunikasi, tergantung fitur apa yang digunakan. Internet pada dasarnya merupakan sebuah jaringan antarkomputer yang saling berkaitan, jaringan ini tersedia secaraterus-menerus sebagai pesanpesan elektronik, termasuk email, transmisi file, dan komunikasi dua arah antar-individu atau komputer?.

Kelebihan jaringan komunikasi internet ini adalah kecepatan mengirim dan memperoleh informasi, dan sekaligus sebagai penyedia data yang shopisticated. Internet juga menjadi penyedia media informasi surat kabar (electronic newspaper), program film, buku baru. ${ }^{10}$

Mahasiswa STAIN Curup dalam menjalankan perannya sebagai agent of change, dituntut untuk terus mengupdate ilmu dan informasi khususnya berkenaan dengan studi mereka. Kebutuhan inilah yang membuat mahasiswa harus terus menambah referensi penunjang studi. Selain buku, jurnal cetak dan modul, internet menjadi salah satu sumber referensi yang digunakan oleh mahasiswa. Mahasiswa sebagai khalayak aktif menggunakan dan memilih media yang dapat memenuhi kebutuhannya. Untuk mengukur keaktifan khalayak, bisa dilihat dari pemilihan media guna memenuhi kebutuhan penerima, baik dalam pemenuhan kebutuhan akan informasi dan pelepasan, pelarian dari stres/ hiburan. Mudahnya mengakses internet juga menjadi salah satu daya tarik mahasiswa untuk memilih media ini. Hanya dengan mengetik keyword tertentu, internet dapat menyajikan banyak artikel yang berhubungan dengan kata kunci yang dicari.

Kebutuhan yang tinggi akan mendia massa, tak lepas dari fungsi media massa itu sendiri, Jay Black dan Frederick C. Whitney ${ }^{11}$ (1988) menyatakan ada beberapa fungsi komunikasi, antara lain: (1) to inform (menginformasikan), (2) to entertain (memberi hiburan), (3) to persuade (membujuk), dan (4) transmission of the culture (transmisi budaya).

Selain manfaat yang melekat pada fungsi media massa, internet juga mempunyai dampak bagi penggunanya berupa efek komunikasi. Untuk mengkaji pemanfaatan dan dampak penggunaan media massa bagi mahasiswa selaku khalayak yang aktif, perlu adanya kajian yang lebih jauh mengenai, bagaimana pemanfaatan internet sebagai referensi mahasiswa STAIN Curup? bagaimana dampak penggunaan internet sebagai referensi mahasiswa STAIN Curup?

${ }^{8}$ Nurudin, Komunikasi Massa, (Yogyakarta: Cespur, 2004), 12

${ }^{9}$ Werner J. Severin dan James W. Tankard, Jr, Teori Komunikasi: Sejarah, Metode, dan Terapan di Dalam Media Massa, (Jakarta: Kencana, 2008), 8

${ }^{10}$ Hafied Cangara, Pengantar Ilmu Komunikasi, (Jakarta: Remaja Geafindo Persada, 2015), 163

${ }^{11}$ Nurudin, 62 


\section{Metode Penelitian}

\section{Jenis Penelitian}

Penelitian ini menggunakan metodologi kualitatif untuk mengungkapkan realitas penggunaan dan dampak penggunaan internet bagi mahasiswa STAIN Curup. Menurut Denzin dan Lincoln (1988:3) penelitian kualitatif adalah penelitian yang bersifat interpretif (menggunakan penafsiran) yang melibatkan banyak metode, dalam menelaah masalah penelitiannya. Penelitian kualitatif atau paradigma interpretif pada penelitian ini didukung oleh sejumlah teori antara lain teori uses and gratifications dan teori efek media massa. Moleong berpendapat bahwa dalam penelitian kualitatif, teori dibatasi pada pengertian: suatu pernyataan sistematis yang berkaitan dengan seperangkat proposisi yang berasal dari data dan diuji kembali secara empiris. Moleong menjelaskan bahwa orientasi teoritis atau perspektif teoritis sering disebut sebagai paradigma yang diartikan sebagai kumpulan longgar tentang asumsi yang secara logis dianut bersama, konsep atau proposisi yang mengarahkan cara berfikir dan cara penelitian ${ }^{12}$. Berbeda dengan Moleong Mulyana menjelaskan bahwa prespektif seringkali disebut sebagai pendekatan sedangkan Creswell menyebutnya sebagai tradisi ${ }^{13}$. Maka dari itu, penelitian ini menggunakan tradisi atau pendekatan kualitatif, dimana penelitian ini berupaya menggambarkan pemandaatan dan dampak penggunaan media massa.

Subjek penelitian atau informan akan dibagi menjadi informan kunci dan informan pelengkap. Informan dalam penelitian ini adalah mahasiswa STAIN Curup, sedangkan informan lainnya adalah dosen STAIN Curup, dan pihak-pihak yang terlibat dalam pemenuhan kebutuhan referensi mahasiswa.

\section{Teknik Pengumpulan dan Analisis Data}

Adapun teknik pengumpulan data yang dilakukan dalam penelitian ini adalah: wawancara, observasi, studi dokumentasi. Untuk mejawab masalah penelitian dan memperoleh makna sebenarnya dari fenomena yang diteliti, perlu dilakukan anlisis datadata yang telah dihimpun. Langkah-langkah analisis data adalah: ${ }^{14}$ reduksi data, penyajian data, penarikan kesimpulan dan pemaknaan

\section{Hasil Penelitian dan Pembahasan}

\section{Pemanfaatan Internet Sebagai Referensi Mahasiswa STAIN Curup}

Untuk melihat pemanfaatan internet sebagai sumber referensi mahasiswa STAIN Curup dalam aspek internet sebagai media massa, penelitian ini dipandu melalui pendekatan uses and gratifications. Pendektan ini berfokus pada konsumen-anggota audience-ketimbang pada pesannya. ${ }^{15}$ Pendekatan ini melihat audiens media massa

\footnotetext{
${ }^{12}$ Engkus Kuswarno, Fenomenologi, (Bandung: Widya Padjadjaran, 2009), 127

${ }^{13}$ Kuswarno, 127

${ }^{14}$ Sugiono, 92

15 Stephen W. Littlejohn dan Karen A. Foss, Teori Komunikasi, (Salemba Humanika,
} Jakarta: 2011), 426 
sebagai kelompok yang aktif dalam menentukan dan memilih media yang akan dikonsumsi untuk memperoleh kepuasan. Dalam pandangan ini media dianggap sebagai satu-satunya faktor yang mendukung bagaimana kebutuhan terpenuhi, dan audiens dianggap sebagai perantara yang besar: mereka tahu kebutuhan mereka dan bagaimana memenuhi kebutuhan tersebut. ${ }^{16}$

Untuk melihat pemanfaatan internet sebagai referensi mahasiswa, penelitian ini akan menganalisis dari kebutuhan mahasiswa akan penggunaan internet. Salah satu faktor yang penting dalam penerimaan pesan adalah kebutuhan. Kebutuhan atau motif lain setelah kebutuhan dasar, meliputi kontak sosial, eksplorasi dan komprehensi realitas, sosialisasi, diversi, hiburan, dan permainan, semua itu berkaitan dengan kondisi kesejahteraan jiwa, psikologis, sosial dan komunikasi kita. ${ }^{17}$

Berdasarkan hasil penelitian ada beberapa bentuk kebutuhan mahasiswa terhadap internet, antara lain:

a. Kebutuhan kognitif

Kebutuhan kognitif berkaitan erat dengan peneguhan informasi, pengetahuan di dalam diri individu, serta penyerapan informasi mengenai lingkungannya. Warner ${ }^{18}$ mengutip, kebutuhan kognitif berkaitan dengan memperoleh informasi, pengetahuan dan pemahaman.

Berdasarkan hasil penelitian, penggunaan internet sebagai referensi mahasiswa memenuhi kebutuhan mahasiswa akan informasi, pengetahuan mengenai mata kuliah yang sedang mereka jalani, informasi-informasi terbaru dan pemahaman mengenai lingkungan mereka.

Salah satu faktor yang membuat mahasiswa tertarik untuk menggunakan internet sebagai upaya pemenuhan kebutuhan kognitif mereka adalah mudahnya mengakses internet serta bahan/ materi kuliah yang mereka cari. Mereka tinggal memasukkan keyword judul makalah yang ditugaskan oleh dosen atau tema dalam pembahasan mata kuliah di mesin pencarian, misalnya google. Setelah itu mereka tinggal memilih dari daftar yang muncul. Ada sebagian mahasiswa yang memilih dari urutan teratas dari hasil penelusuran mesin pencarian, ada yang membukanya terlebih dahulu, satu persatu sambil membandingkan kelengkapan isi masing-masing sumber. Ada yang mencari khusus langsung alamat web tertentu, misalnya wikipedia, atau alamat-alamat web serta jurnal online yang direkomendasikan oleh dosen mereka.

Dalam pemanfaatan internet sebagai referensi mahasiswa, ada beberapa dosen yang memberikan kebebasan sepenuhnya dalam pencarian. Dalam artian dosen memberikan kebebasan dalam pencarian referensi di internet maupun dari sumber lainnya.

Ada juga sebagian dosen yang memperbolehkan penggunaan internet tetapi tetap memberikan rambu-rambu dalam pemanfataannya. Misalnya, boleh

${ }^{16}$ Littlejohn, 426

17 Brent. D Ruben dan Lea P. Stewart, Komunikasi dan Perilaku Manusia, Jakarta, Raja Grafindo Persada: 2013), 115

18 Werner J. Severin dan James W. Tankard, Jr, Teori Komunikasi: Sejarah, Metode, dan Terapan di Dalam Media Massa, (Jakarta, Kencana: 2008), 357 
menggunakan internet sebagai referensi tambahan atau pendamping, dengan tetap mensyaratkan buku seperti referensi utama.

Ada juga yang memperbolehkan mengutip dari alamat situs tertentu yang direkomendasikan dosen, jurnal ilmiah online dan tidak memperbolehkan mengutip dari blog yang penulisnya tidak jelas, atau belum teruji kredibilitasnya.

Berikut penuturan Asri Karolina, salah satu dosen di STAIN Curup:

b. Kebutuhan afektif

Kebutuhan afektif berkaitan dengan peneguhan pengalaman yang menyenangkan dan emosional. Werner mengungkapkan bahwa kebutuhan afektif berhubungan dengan emosional, pengalaman menyenangkan atau estetis. ${ }^{19}$

Melalui akses internet, mahasiwa memperoleh peneguhan pengalaman yang emosional. Hal ini tercermin dari mengakses video, film, atau artikel mengenai kisahkisah yang emosional. Misalnya kisah tentang kejadian luar biasa yang diakses di youtube, atau film-film drama yang menguras emosi mahasiswa.

Selain dari pada itu ada beberapa anjuran referensi dari dosen berupa video atau film tertentu yang memberikan pengalaman menyenangkan dan emosional, seperti kisah sahabat nabi.

c. Kebutuhan integratif personal

Kebutuhan integratif secara personal berhubungan dengan memperkuat kredibilitas, rasa peraya diri, stabilitas, dan status. ${ }^{20}$ Berdasarkan hasil penelitian ada sebagian mahasiswa yang menggunakan internet untuk memenuhi kebutuhan integratif secara personal akan tetapi sebagian lainnya masih ragu, khususnya mengenai pemanfaatan internet sebagai referensi mahasiswa STAIN Curup.

Kelompok pertama. Sebagian mahasiswa menjadi percaya diri mengambil referensi dari internet untuk mencari materi kuliah, mencari referensi tugas individu maupun kelompok. Khususnya jika materi yang mereka ambil dari situs yang terpercaya seperti jurnal ilmiah atau alamat web yang direkomendasikan dosen.

Kelompok kedua. Sebagian mahasiswa lainnya merasa kurang percaya diri jika sepenuhnya mengandalkan informasi dari internet sebagai sumber referensi. Mereka akan lebih percaya diri jika ditunjang oleh referensi dari buku.

Sebagian mahasiswa juga merasa status dan kredibilitas mereka menjadi diakui dengan mengakses internet. Hal ini khususnya mengenai update informasi terbaru, fashion, film, sehingga predikat "anak gaul" atau anak "jaman now" menjadi salah satu indikator kredibel bagi mereka. Berdasarkan hasil observasi, ketika peneliti ngobrol santai di kelas, dan bertanya: siapa yang suka update status? Kompak mahasiswa satu kelas menunjuk pada orang tertentu. Begitu juga ditanya, siapa yang suka nonton drakor (drama korea)? Mereka juga kompak akan menunjuk orang tertentu. Sehingga dengan mengakses internet status mereka menjadi diakui, meskipun jika melihat contoh diatas, mahasiswa tersebut diakui statusnya sebagai "Ratu FB (Facebook)" dan "Ratu Drakor (Drama Korea)".

${ }^{19}$ Severin,. 357

${ }^{20}$ Severin, 357 
d. Kebutuhan integratif sosial

Kebutuhan integratif secara sosial dapat dilihat seperti mempererat hubungan dengan keluarga, teman, dan sebaginya. ${ }^{21}$ Salah satu kebutuhan manusia adalah menjalin hubungan dan komunikasi dengan orang lain. Hal ini merupakan naluri dasar manusia sebagai makhluk sosial. Orang yang tidak pernah berkomunikasi dengan manusia bisa dipastikan akan "tersesat", karena ia tidak sempat menata dirinya dalam suatu lingkungan sosial. Komunikasilah yang memungkinkan individu membangun suatu kerangka rujukan dan menggunakannya sebagai panduan untuk menafsirkan situasi apa pun yang ia hadapi. Komunikasi pula yang memungkinkannya mempelajari dan menerapkan strategi-strategi adaptif untuk mengatasi situasi-situasi problematik yang ia masuki ${ }^{22}$.

Berdasarkan hasil penelitian dalam menjalankan hubungan dengan orang lain, penggunaan internet dapat menjadi salah satu sarana yang mumpuni. Misalnya melalui aplikasi sosial media, mahasiswa menjalin hubungan dengan keluarga, teman, dan masyarakat. Mahasiswa dengan handphone yang mampu mengakses internet mengakui mereka mempunyai grup-grup di sosial media untuk memenuhi kebutuhan ini. Misalnya grup di aplikasi Whats App (WA) seperti grup kelas (satu angkatan/ satu kelas), grup organisasi, grup alumni SMA, bahkan ada yang mempunyai grup "gank", grup yang terdiri dari beberapa orang teman akrab saja. Yang kesemuanya merupakan peneguhan kontak dengan orang lain.

Di satu sisi, internet membuat kebutuhan integratif sosial terpenuhi, misalnya peneguhan kontak dan hubungan dengan keluarga, teman, lingkungan. Sementara di sisi lain sebagian mahasiswa merasa dengan adanya fasilitas di Internet yang semakin memudahkan komunikasi hubungan dengan saudara yang jauh, teman-teman, alumni. Sedangkan mereka juga merasa menjadi jauh dengan keluarga inti di rumah. Akan tetapi berdasarkan hasil penelitian ada beberapa mahasiswa yang "rame" ketika di grup kelas, tetapi ketika berjumpa di kampus secara nyata, sangat bertolak belakang. mereka menjadi canggung dan kikuk. Sebagian mahasiswa yang lain, yang tinggal dengan orang tuanya lain merasa lebih jauh dengan keluarga di rumah.

e. Kebutuhan pelepasan

Mahasiswa juga menggunakan internet untuk memenuhi kebutuhan pelepasan. Kebutuhan pelepasan berkaitan dengan pelarian dan pengalihan ${ }^{23}$. Salah satu yang menjadi tekanan dalam kuliah khususnya mengenai tugas adalah keterbatasan referensi. Untuk wilayah kabupaten Rejang Lebong hampir tidak ada toko buku yang mengcover kebutuhan buku referensi mahasiswa. Untuk perpustakaan STAIN Curup sendiri masih terbatas dalam ragam judul buku dan jumlahnya. Sehingga salah satu upanya untuk menghindari tekanan dari keterbatasan referensi adalah dengan mengakses internet. Selain itu akses internet juga untuk melakukan pelepasan terhadap rutinitas kampus, dan pelarian dari masalah dengan keluarga atau teman.

${ }^{21}$ Severin, 357

${ }^{22}$ Deddy Mulyana, Ilmu Komunikasi: Suatu Pengantar, (Bandung: Remaja Rosdakarya, 2005), 6

${ }^{23}$ Severin, 357 


\section{Kepuasan dalam Penggunaan Media Massa}

Mahasiswa selaku audiens media massa di lihat secara manusiawi, dengan kedinamisannya. Dalam pemanfaatan media massa, akan timbul kepuasan dalam diri mahasiswa jika semua kebutuhannya akan media massa terpenuhi. Untuk melihat kepuasan mahasiswa terhadap penggunaan internet sebagai sumber referensi, dapat dilihat dari fungsi media massa itu sendiri.

a. Fungsi Informasi

Fungsi informasi pada media massa secara luas mencakup: pengumpulan penyimpanan, pemrosesan, penyebaran berita, data, gambar, fakta dan pesan, opini dan komentar, yang dibutuhkan agar orang dapat mengerti dan bereaksi secara jelas terhadap kondisi internasional, lingkungan, dan orang lain, dan agar dapat mengambil keputusan yang tepat ${ }^{24}$.

Berdasarkan hasil penelitian, mahasiswa menggunakan internet sebagai rujukan dan sumber informasi salah satunya dalam menunjang proses belajar mengajar di bangku perkulihan.

Dalam pemenuhan informasi sebagai salah satu sumber referensi mahasiswa, internet memegang peranan yang signifikan. Berdasarkan temuan dilapangan sebagian besar mahasiswa sangat mengandalkan internet sebagai sumber referensi. Jika dipersentasekan dengan sumber referensi lainnya maka penggunaan internet sebagai sumber referensi mahasiswa lebih dari $60 \%$, sedangkan media lain sebanyak $40 \%$. Ada sebagian mahasiswa yang mengambil sepenuhnya referensi dari internet tanpa ditunjang dengan sumber referensi lainnya. Artinya penggunaan internet sebagai sumber referensi dipersentasekan sebanyak 100\%.

b. Fungsi Hiburan

Hiburan (entertainment) merupakan fungsi media massa. Mengenai hal ini memang jelas tampak pada televisi, film dan rekaman suara. Media massa lainnya seperti surat kabar dan majalah, meskipun fungsi utamanya adalah informasi dalam bentuk pemberitaan, rubrik-rubrik hiburan selalu ada, apakah itu cerita pendek, cerita panjang, atau cerita bergambar ${ }^{25}$. Fungsi hiburan juga melekat pada internet sebagai media massa. seperti banyak situs-situs penyedia film, cerita-cerita yang memberikan dan mampu merilekskan pikiran setelah diterpa konten-konten berat atau pelepasan dari rutinitas yang menguras pikiran.

Fungsi hiburan, metupakan fungsi lainnya dari media massa. selain untuk memperoleh informasi, internet juga dimanfaatkan oleh mahasiswa STAIN Curup untuk memperoleh hiburan. Salah satu pemenuhan hiburan dapat diperoleh dengan mengakses film-film, musik, talkshow, ceramah, game online, bersosial media, serta situs karaoke online. Berdasarkan hasil penelitian mahasiswi melakukan pelepasan dengan mengakses film-film seperti film-film dalam negeri, western, film/drama 2003), 27

${ }^{24}$ Onong Uchjana Effendy, Komunikasi: Teori dan Praktek,(Bandung,: Remaja Rosdakarya, ${ }^{25}$ Effendy, 31 
korea, film Bolywood film animasi, cuplikan/petikan tanyangn televisi baik nasional maupun internasional, tahfidz Qur'an, liputan/rekaman pertandingan olahraga, sosial media, situs karaoke. Sedangkan mahasiswa lebih sering mengakses game online, film, situs karaoke, pertandingan olah raga, dan lain sebagainya untuk merilekskan pikiran.

Dalam kaitannya dengan sumber referensi, mahasiswa mengakui tidak semua materi kuliah atau tugas memberatkan dan hanya melulu soal informasi. Mereka juga mengakses ceramah, film-film tertentu, untuk menunjang performa di mata kuliah mereka yang notabenenya masuk sekaligus sebagai fungsi hiburan.

c. Fungsi Persuasi

Fungsi persuasi (to persuade) erat kaitannya dengan sifatnya membujuk, mempengaruhi (to influence). Persuasi dapat datang dalam banyak bentuk ${ }^{26}$ :

1) Mengukuhkan atau memperkuat sikap, kepercayaan, atau nilai seseorang.

2) Mengubah sikap, kepercayaan, atau nilai seseorang

3) Menggerakkan seseorang untuk melakukan sesuatu, dan

4) Memperkenalkan etika, atau menawarkan sistem nilai tertentu.

Fungsi mempersuasi dapat dilihat dengan jelas pada iklan di internet. Terkadang iklan-iklan di internet langsung muncul ketika kita mengakses situs tertentu. Ada yang menempati space tertentu dari halaman web, misalnya di bagian atas, bawah, atau samping, bahkan ada juga yang langsung muncul menutupi bagian halaman isi/ halaman web.

Bagi sebagian mahasiswa, iklan yang muncul ketika mereka sedang browsing cukup mengganggu, akan tetapi sebagian dari mereka tidak terpengaruh dengan konten iklan tersebut.

Sebagian lainnya merasa tertarik dengan konten iklan tertentu, misalnya produk kecantikan, fashion, khususnya yang dikenakan public figure.

Persuasi berupa peneguhan dan dan perkenalan nilai-nilai baru, juga di dapat melalui akses internet. Misalnya ketika dosen mengakses ceramah atau film-film tertentu yang merupakan bagian atau media pembelajaran mata kuliah, mahasiswa memperoleh nilai-nilai baru.

d. Transmisi Budaya dan Pewarisan Sosial

Dalam transmisi budaya dan pewarisan sosial juga terdapat transmisi nilainilai seperti sosialisasi. Sosialisasi merupakan transmisi nilai-nilai (transmission of values) yang mengacu kepada cara-cara di mana seseorang mengadopsi perilaku dan nilai-nilai dari suatu kelompok. ${ }^{27}$

Mahasiswa memperoleh nilai-nilai baru melalui akses internet seperti dari film-film, liputan tentang sebuah masyarakat atau kelompok, nasehat-nasehat spiritual. Mahasiswa mempelajari dan mempersepsi nilai baru tersebut, dan meneguhkan nilai-nilai yang mereka anut.

${ }^{26}$ Joseph. A. Devito, Komunikasa Antarmanusia: Kuliah Dasar., terj. Agus Maulana, (Jakarta: Professional Books, 1997), 515

${ }^{27}$ Effendy, 31 
Transmisi budaya juga untuk memajukan kebudayaan dalam bentuk penyebarluasan hasil kebudayaan dan seni dengan maksud melestarikan warisan masa lalu, perkembangan kebudayaan dengan memperluas horizon seseorang, membangunkan imajinasi dan mendorong kreativitas serta kebutuhan estetikanya. ${ }^{28}$

Melalui akses internet, sebagian mahasiswa menjadi tahu dan kenal serta paham dengan kebudayaannya sendiri dan kebudayaan-kebudayaan lainnya yang ada di dunia. Hal ini bukan hanya menambah informasi dan pengetahuan bagi mahasiswa, tetapi proses transmisi budaya sehingga budaya tetap lestari dan tidak lenyap ditelan zaman.

e. Korelasi (Menghubungkan)

Media massa mempu menghubungkan (linkage) unsur-unsur yang terdapat di dalam masyarakat yang tidak bisa dilakukan secara langsung oleh saluran perseorangan ${ }^{29}$. Internet mampu membuat mahasiswa terhubung dengan komponen-komponen lain dari masyarakat, misalnya: menghubungkan antara mahasiswa dengan penjual melalui iklan di internet. Mampu menghubungkan mahasiswa dengan komunitas gameonline dan fans club aktris atau aktor baik dalam maupun luar negeri. Internet juga membuat budaya K Pop (Korean Pop = musik pop Korea) menjadi dikenal oleh mahasiswa STAIN Curup. Bahkan ada mahasiswa STAIN Curup, manjalankan bisnis online di internet sebagai sarana untuk menemukan konsumennya.

Mahasiswa STAIN Curup dalam memanfaatkan internet sebagai sumber referensi didasari atas beberapa kebutuhan antara lain' kebutuhan kognitif, kebutuhan afektif, kebutuhan integrasi personal, serta kebutuhan pelepasan. Kepuasan akan timbul, diri individu ketika membutuhkan terpenuhi setelah menggunakan internet sebagai sumber referensi mahasiswa STAIN Curup. Sebagian mahasiswa merasa sangat puas, sementara sebagian yang lainnya merasa kurang puas jika tidak ditunjang oleh sumber referensi lainnya. Untuk menganalisis kepuasan terhadap pengguna internet sebagai referensi mahasiswa peneliti menilik melalui fungsi media massa itu sendiri, antara lain: fungsi informasi, fungsi hiburan, fungsi persuasi, fungsi transmisi budaya dan pewarisan sosial dan fungsi korelasi. Dimana berdasarkan hasil penelitian, kesemua fungsi media massa tersebut dirasakan oleh mahasiswa STAIN Curup, khususnya dalam penggunaan internet sebagai referensi.

${ }^{28}$ Effendy, 28

${ }^{29}$ Effendy, 30 


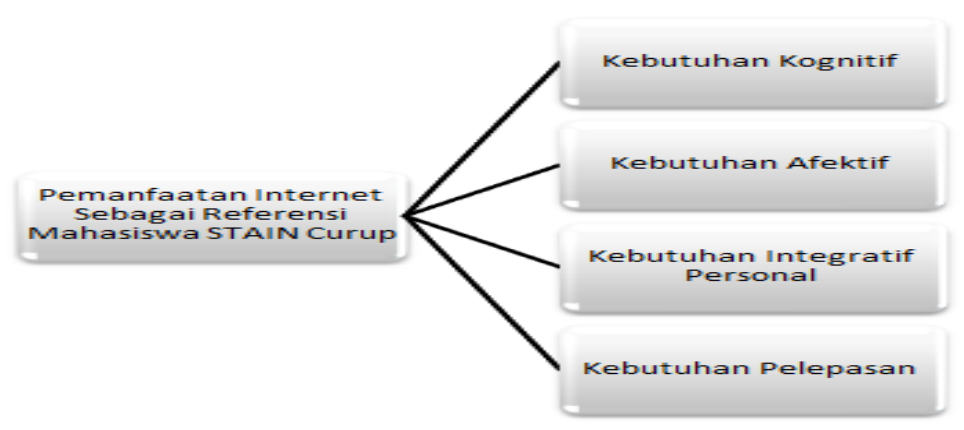

Sumber: Hasil Penelitian

\section{Dampak Penggunaan Internet Sebagai Referensi Mahasiswa STAIN Curup}

Dalam proses komunikasi, setelah partisipan komunikasi diterpa pesan, makan akan timbul efek/dampak pada diri partisipan. Begitu juga dengan mahasiswa STAIN Curup, ketika diterpa pesan atau informasi dari internet, membawa dampak/efek tertentu pada diri mahasiswa.

Dampak atau efek media massa jika mengunakan pendekatan subjektif, maka akan memberikan hasil yang berbeda-beda, tergantung dengan beberapa faktor yang mempengaruhinya. Salah satu model komunikasi yang yang memfokuskan pada unsurunsur komunikasi termasuk efek adalah model Lasswell. Model Lasswell sering diterapkan dalam komunikasi massa. Model komunikasi Lasswell berupa ungkapan verbal, yakni ${ }^{30}$ :

\section{"Who Says What In Which Channel To Whom With What Effect?"}

Unsur sumber (who) merangsang pertanyaan mengenai pengendalian pesan, sedangkan unsur pesan (says what) merupakan bahan untuk analisis isi. Saluran komunikasi (in which channel) dikaji dalam analisis media. Unsur penerima (to whom) dikaitkan dengan analisis khalayak, sementara unsur pengaruh (with what effect) jelas berhubungan dengan studi mengenai akibat yang ditimbulkan pesan komunikasi massa pada khalayak pembaca, pendengar, atau pemirsa. ${ }^{31}$ Efek (effect, impact, influence) sebagai salah satu unsur komunikasi yang di fokuskan dalam formula Lasswell. Effect analysis merupakan penelitian mengenai efek atau dampak yang ditimbulkan oleh komunikasi ${ }^{32}$.

${ }^{30}$ Mulyana, 147-148

${ }^{31}$ Mulyana, 148

${ }^{32}$ Effendy, 10 
Melihat efek penggunaan internet oleh mahasiswa, maka efek moderatlah yang sesungguhnya dirasa tepat untuk menganalisisnya. Teori peluru, salah satu gagasan paling awal dan paling sederhana tentang komunikasi massa, mengganggap dampak yang benar-benar kuat disebabkan oleh komunikasi massa. Tetapi setelah beberapa waktu berlalu, gagasan ini digantikan oleh model dampak terbatas. Riset terus berkembang, yang menunjukkan bahwa komunikasi massa mempunyai lebih dari sekedar dampak terbatas. Pandangan ini disebut dengan model dampak moderat (moderate effects model); ide yang menyatakan model dampak terbatas telah terlalu jauh dalam meminimalkan dampak komunikasi massa ${ }^{33}$. Dalam efek moderat ada beberapa faktor yang mempengaruhi penerimaan terhadap pesan. Faktor- faktor ini mempengaruhi efek/ dampak terpaan pesan dari internet terhadap mahasiswa STAIN Curup. Faktor-faktor ini, antara lain: ${ }^{34}$

a. Faktor individu.

Faktor individu yang ikut berpengaruh pada proses penerimaan pesan lebih banyak dipengaruhi oleh pemikiran psikologis. Faktor individu seperti Selective attention adalah individu yang cenderung menerima terpaan pesan media massa yang sesuai dengan pendapat dan minatnya. Selective perceptions menggiring seseorang secara sadar untuk mencari dan mengkonsumsi media yang mendorong kecenderungan dirinya, selective retention adalah kecenderungan seseorang hanya untuk mengingat pesan yang sesuai dengan pendapat dan kebutuhan dirinya sendiri. Selain dari pada itu faktor individu lainnya adalah motivasi dan pengetahuan, kepercayaan, pendapat, nilai, dan kebutuhan, pembujukan, kepribadian dan penyesuaian diri ${ }^{35}$. Tubbs mengugkapkan kalau terpaan selektif (selective exposure) itu nyata, dimana seseorangakan cenderung untuk emilih komunikasi yang akan menegaskan pendapat, sikap, dan nilai-nilai pada diri individu itu sendiri. Ketika diterpa pesan komunikasi seseorang juga akan melakukan atensi selective dimana penerima akan memproses stimuli tertentu yang tersedia dan menyaring stimuli lainnya. ${ }^{36}$ Dalam pemanfaatan internet mahasiswa memilih sesuai dengan minat, kebutuhannya masing-masing. Misalnya penggemar film Korea akan lebih tertarik dan mudah menerima pesan-pesan yang terkandung dalam film Korea tersebut. Mahasiswa dalam mengunakan internet sebagai referensi, memilih dari berbagai artikel dan alamat website yang sesusai dengan minat dan kebutuhannya dalam hal ini adalah bertujuan untuk mencari materi kuliah maupun tugas mata kuliah.

b. Faktor sosial

Faktor sosial yang ikut mempengaruhi proses penerimaan pesan antara lain: umur dan jenis kelamin, pendidikan dan latihan, pekerjaan dan pendapat, agama,

${ }^{33}$ Severin, 318-319

${ }^{34}$ Nurudin, Komunikasi Massa, (Yogyakarta: Cespur, 2004), 214-221

${ }^{35}$ Nurudin, 124-221

${ }^{36}$ Stewart L. Tubbs dan Sylvia Moss, Human Communication: Konteks-Konteks Komunikasi.diterjemabkan oleh Deddy Mulyana dan Gembirasari, (Bandung, Remaja Rosdakarya: 2001), h. 209-210 
tempat tinggal. ${ }^{37}$ Berdasarkan hasil penelitian rentang umur mahasiswa STAIN antara 19-23 tahun, berjenis kelamin perempuan dan laki-laki, dengan latar pendidikan lulusan Sekolah Menengah Atas (SMA), Madrasah Aliyah (MA), serta pondok pesantren. Sebagian mahasiswa STAIN Curup masih dibiayai oleh orang tua, hanya sebagian kecil yang punya usaha atau penghasilan sendiri. Seluruh informan penelitian ini beragama Islam. Mahasiswa dari luar kota, biasnya menyewa rumah/kos/tinggal di asrama mahasiswa, sedangkan yang berasal dari dalam kota tinggal bersama orang tua atau keluarnya.

Peggunaan/pemanfaatan internet sebagai referensi oleh mahasiswa STAIN Curup, masuk dalam kategori proses komunikasi multi-langkah. Dimana orang yang membuka diri terhadap satu media seringkali juga akan terbuka terhadap media yang lain. Tidak terhindarkan bahwa hal yang sama dan hal yang baru diberitakan di banyak media yang berbeda. Selanjutnya kita harus mengasumsikan bahwa interaksi antarpribadi terjadi di antara paparan-paparan (exposures) media. Selama pemaparan ini (baik terhadap media maupun dalam interaksi antarpribadi), kita dipengaruhi dan mempengaruhi yang lain. ${ }^{38}$ Teori ini penting dalam mengilustrasikan bahwa setiap orang dipengaruhi baik oleh media maupun oleh interaksi antarpribadi, dan selanjutnya mempengaruhi media dan orang lain.

Gambar. Teori Pengaruh Media Multi Langkah

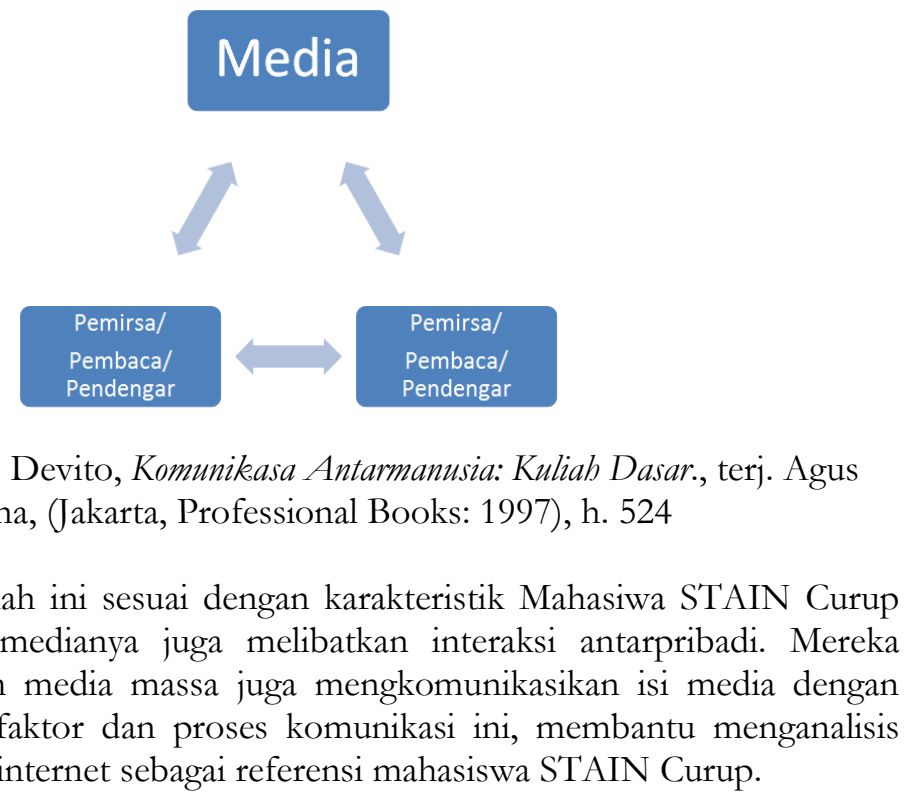

${ }^{37}$ Nurudin, 214-221

${ }^{38}$ Devito, h. 524 
Melihat kehidupan dan interaksi bermedia mahasiswa yang dinamis, ada beberapa dampak/efek penggunaan internet sebgai referensi mahasiswa STAIN Curup, antara lain:

a. Dampak kognitif

Dampak kognitif terjadi apabila audiens yang diterpa pesan komunikasi massa mengalami perubahan tentang apa yang diketahuinya, dipahaminya, atau dipersepsikannya. Mahasiswa STAIN Curup ketika mengakses internet juga mengalami perubahan pengetahuan dan informasi yang dia miliki. Akan tetapi dampak perubahan kognitif berbeda-beda dipengaruhi oleh berbagai faktor-faktor yang telah dibahas sebelumnya (faktor individu dan faktor sosial). Sehingga terpaan media massa tidak berdiri sendiri melainkan melibatkan unsur-unsur lainnya atau dengan kata lain dampak/efek penggunaan internet bagi mahasiswa juga dipengaruhi oleh faktor-faktor lainnya.

Berdasarkan hasil penelitian, mahasiswa mengalami adanya perubahan tentang informasi dan pengetahuan yang ia miliki. Dari sebelumnya tidak tahu atau kurang jelas mengenai topik atau tema yang menjadi tugas atau bahan diskusi (makalah), menjadi lebih jelas. Akan tetapi tidak semua mahasiswa mengakses internet sebagai sumber referensi menerima informasi yang utuh. Mahasiswa yang memperoleh informasi secara utuh, dalam artian ketika melakukan pencarian materi tugas/makalah mereka memilih, membaca, dan membandingkan informasi secara menyeluruh. Ada proses seleksi di dalamnya untuk memperoleh informasi yang semakin banyak. Terkadang mahasiswa juga membandingkan isi materi di internet dengan sumber lain dari internet, bahkan juga membandingkan isi internet dengan ini buku referensi. Jadi informasi dari internet saling melengkapi dengan sumber referensi lainnya.

Sebagian mahasiswa sedikit melakukan seleksi dalam penerimaan pesan dari internet. Dalam artian, setelah memasukkan keyword pada "mesin pencarian" mereka hanya memilih dari daftar teratas dari hasil pencarian. Selanjutnya dibaca sedikit apakah sesuai tema, dan langsung memindahkan informasi tersebut menjadi bagian dari isi tugas/makalah tanpa membaca secara utuh atau membandingkannya dengan sumber-sumber lain dari internet maupun dari buku dan modul kuliah.

Sebagian mahasiswa lebih yakin akan informasi yang di dapat dari internet jika sumber/link yang mereka kunjungi adalah rekomendasi/ saran dari dosen yang mengampu mata kuliah. Sebagian mahasiwa juga punya link favorit, yang mereka anggap lengkap, terpercaya dan lebih mudah dimengerti, misalnya; www.id.wikipedia.org.

b. Dampak afektif

Dampak/efek afektif terjadi apabila pesan media massa yang diterima audiens mampu mengubah perasaan, emosi, sikap atau nilai-nilai penerima pesan. Dampak ini adalah dampak lanjutan dari dampak kognitif.

Mahasiswa STAIN Curup ketika mengakses berbagai macam fasilitas yang ada di internet juga mengalami perubahan pada emosi, sikap, dan nilai yang mereka yakini. Dampak afektif ini juga berbeda-beda pada masing-masing individu. 
Berdasarkan hasil penelitian, setelah mengakses film dari berbagai genre, game, tayangan khusus, misalnya ceramah, cuplikan kejadian-kejadian aneh, luar biasa, berita-berita terbaru dan sensasional, sebagian mahasiswa mengalami perubahan perasaan, sikap dan nilai-nilai yang mereka internalisasi.

Sebagian mahasiswa merasa terjadi perubahan perasaan, emosi, dan nilainilai setelah mengakses internet sebagai sumber referensi seperti ketika referensi itu berupa film-film kisah nyata, rekaman ceramah, sejarah dan kehidupan para sahabat dan Nabi, film-film dokumenter. Sebagian mereka berpendapat bahwa menggunakan media pembelajaran audio visual seperti film, mereka menjadi lebih antusias dan lebih menarik dari pada hanya materi tertulis.

c. Dampak konatif/ behavioral

Ketika audiens diterpa pesan dari media massa dan terjadi dorongan untuk melakukan sebuah tindakan, maka pada tahap ini audiens telah memperoleh efek konatif/behavioral dari media massa. Jika pada efek konatif terjadi perubahan informasi dan pengetahuan, efek afektif terjadi perubahan pada perasaan, sikap, dan nilai, maka pada tahap konatif/behavior telah terjadi aksi nyata, berupa perubahan perilaku/ dorongan untuk melakukan sesuatu.

Mahasiswa STAIN Curup ketika diterpa pesan media massa juga merasakan efek konatif/ behavioral yang berbeda-beda. Hal ini terlihat pada terpaan media massa khususnya berita-berita, misalnya mengenai bencana alam. Sebagian mahasiswa akan membuka posko untuk menggalang dana dan menyalurkanya pada korban secara langsung ata melalui lembaga-lembaga bantuan bencana nasional.

Materi-materi di kelas yang ditunjang oleh tugas baik tugas individu maupun tugas kelompok, tentang masalah ibadah, kamatian, dosa-pahala, adzab, juga memberikan dampak konatif/behavioral bagi sebagian mahasiswa.

Dampak konatif yang terlihat adalah perubahan perilaku pengguna internet. Sebagian besar mahasiswa menjadi tergantung dengan innformasi-informasi atau terlalu mengandalkan internet sebagai sumber referensi. Jika diberikan tugas oleh dosen, maka internetlah yang akan manjadi sumber referensi. Berdasarkan hasil observasi sebagian mahasiswa ketika diskusi dikelaspun, internetlah tempat mereka mencari jawaban dari pertanyaan yang muncul dalam diskusi, bukan dari makalah yang mereka buat atau berdiskusi dengan anggota kelompoknya. 


\section{Gambar . Model Dampak Penggunaan Internet}

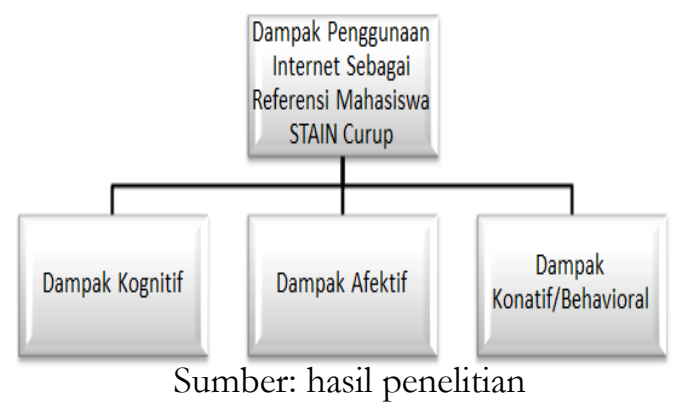

Saat ini teknologi media baru memberi peluang bagi individu untuk menyesuaikannya dengan kebutuhan, merancang sesuai selera, dan mengkreasikan isi media seperti blog, halaman facebook, catatan harian video youtube dan portal ${ }^{39}$. Kebutuhan internet yang tinggi menjadikan mahasiswa tak luput dari terpaan efek komunikasi. Pada kenyataanya, terpaan pesan bukanlah satu-satunya penentu efek dan dampak pengguna internet oleh mahasiswa STAIN Curup. Ada faktor-faktor penunjang lainnya yang ikut mempengaruhi efek/dampak yang timbul pada mahasiswa antara lain faktor dari individu maupu faktor sosial. Hal lain yang menguatkan efek/dampak dari penggunaan sebagai referensi mahasiswa antara lain exposure/jangkauan pesan, dalam artian apabila mahasiswa secara luas terpapar pesan dari media massa. Selanjutnya adalah kredibilitas, dan dampak akan semakin kuat jika mahasiswa menganggap situs/web yang mereka jadikan sebagai sumber referensi mempunyai kredibilitas tinggi jika merupakan rekomendasi dari dosen atau dari jurnal ilmiah online.

Konsonansi terjadi apabila pesan media massa relatif sama dan serupa penyebarannya dari berbagai media. Sebagian mahasiswa STAIN Curup mereka memilih referensi dari internet yang terdapat kutipan dari buku. Jadi artikel di internet tersebut bersumber dari buku. Hal lainnya yaitu significant. Mahasiswa akan mencari/mengambil referensi dari internet yang sesuai dengan materi/tema tugas yang mereka butuhkan. Yang semakin menguatkan terpaan pesan media massa adalah dukungan komunikasi antarpribadi. Efek media massa akan semakin kuat jika ditunjang oleh dukungan komunikasi antarpribadi. Hal ini terlihat jika mahasiswa mengambil referensi dari internet dan isi pesan dari internet tersebut dibenarkan atau sama dengan pendapat mahasiswa lainnya maupun dosen pengampu mata kuliah. Maka akan semakin menguatkan dampak/efek komunikasi massa tersebut.

\section{Penutup}

\section{Kesimpulan}

${ }^{39}$ Charles R. Berger, Dkk, Handbook Ilmu Komunikasi, (Bandung: Nusa Indah, 2015), 
Mahasiswa STAIN Curup dalam memanfaatkan internet sebagai sumber referensi didasari atas beberapa kebutuhan antara lain: kebutuhan kognitif, kebutuhan afektif, kebutuhan integrasi personal, serta kebutuhan pelepasan. Berkaitan dengan penggunaan internet sebagai referensi, kepuasan akan timbul pada diri mahasiswajikakebutuhannya terpenuhi setelah menggunakan internet. Berdasarkan hasil penelitian, sebagian mahasiswa merasa sangat puas, sementara sebagian yang lainnya merasa kurang puas jika referensi hanya berasal dari internet dan tidak ditunjang oleh sumber referensi lainnya. Kepuasan terhadap penggunaan internet dapat dilihat dari fungsi media massa itu sendiri, antara lain fungsi informasi, fungsi hiburan, fungsi persuasi, fungsi transmisi budaya dan pewarisan sosial, serta fungsi korelasi.

Dampak penggunaan internet sebagai sumber referensi pada mahasiswa STAIN Curup meliputi dampak kognitif, dampak afektif, serta dampak konatif/behavioral. Terpaan pesan bukanlah satu-satunya penentu efek dan dampak pengguna internet oleh mahasiswa STAIN Curup. Ada faktor-faktor penunjang lainnya yang ikut mempengaruhi efek/dampak yang timbul pada mahasiswa antara lain faktor dari individu seperti selective attention, selective perception, dan selective retention, motivasi dan pengetahuan, kepercayaan, pendapat, nilai, dan kebutuhan, pembujukan, kepribadian dan penyesuaian diriserta faktor sosial yang ikut mempengaruhi antara lain: umur dan jenis kelamin, pendidikan dan latihan, pekerjaan dan pendapat, agama, serta tempat tinggal.

\section{Saran}

1. Kepada Pusat Penjamin Mutu (P2M) STAIN Curup

Untuk meningkatkan mutu karya ilmiah mahasiswa, hendaknya P2M membuat pedoman baku dan menyeluruh mengenai ketentuan referensi bagi mahasiswa STAIN Curup.

2. Mahasiswa

a. Bagi mahasiswa untuk memperkaya dan meningkatkan kualitas karya ilmiah hendaknya jangan hanya mengandalkan internet sebagai satu-satunya sumber referensi.

b. Pemanfaatan jurnal ilmiah online, e-book dan sumber referensi kredibel lainnya dari internet, dianjurkan dalam memenuhi kebutuhan akan sumber referensi.

c. Mahasiswa hendaknya dapat bijak dalam peggunaan internet atau berinternet secara sehat agar dapat meminimalisir disfungsi media massa.

\section{Daftar Pustaka}

Jurnal: 
Agus Santoso, Media Literacy Siswa Muslim Surabaya dalam Penggunaan Internet (Jurnal Komunikasi Islam Fakultas Dakwah dan Komunikasi Universitas Islam Negeri (UIN) Sunan Ampel Surabaya, Volume 5, No 1, Juni 2015)

Trisnani, Pola Penggunaan Media Sebagai Pencarian Kebutuban Informasi Masyarkat Nelayan, (Jurnal Komunikasi, Media dan Informatika, Volume 5 No.1/ April 2016)

Wahyudiono, Portal Web Oleh Kelompok Informasi Masyarakat di Kabuaten Lombok Barat, (Jurnal Komunikasi, Media dan Informatika, Volume 5 No. 2/ Agustus 2016)

\section{Buku:}

Berger, Charles R, Dkk. Handbook Ilmu Komunikasi. Bandung, Nusa Indah: 2015

Cangara, Hafied, Pengantar Ilmu Komunikasi. Jakarta, Remaja Geafindo Persada: 2015

Dvito, Joseph. A. Komunikasa Antarmanusia: Kuliah Dasar., terj. Agus Maulana. Jakarta, Professional Books: 1997

Effendy, Onong Uchjana. Komunikasi: Teori dan Praktek. Bandung. Remaja Rosdakarya: 2003

Littlejohn, Stephen W dan Karen A. Foss. Teori Komunikasi. Jakarta, Salemba Humanika: 2011

Madcoms. Mudah menggunakan interne. Andi. Yogyakarta: 2015

Mulyana, Deddy. Ilmu Komunikasi: Suatu Pengantar. Bandung. Remaja Rosdakarya: 2005

Mulyana, Deddy. Metode Penelitian Kualitatif: Paradigma Baru Ilmu Komunikasi dan Ilmu Sosial Lainnya. Bandung, Remaja Rosdakarya: 2006

Nurudin. Komunikasi Massa. Yogyakarta, Cespur: 2004

Rakhmat, Jalaluddin. Psikologi Komunikasi. Bandung, Remaja Rosdakarya: 1999W. Neuman, Lawrence Neuman, Social Research Methods: Qualitative and Quantitative Approaches Fifth Edition. USA, Pearson Education: 1991

Riswandi. Ilmu Komunikasi. Jakarta, Graha Ilmu: 2009

Ruben, Brent. D dan Lea P. Stewart. Komunikasi dan Perilaku Manusia. Jakarta, Raja Grafindo Persada: 2013

Severin, Werner J dan James W. Tankard, Jr, Teori Komunikasi: Sejarah, Metode, dan Terapan di Dalam Media Massa. Jakarta, Kencana: 2008

Sugiono. Memahami Penelitian Kualitatif: Dilengkapi Contoh Proposal dan Laporan Peneltian. Bandung, Alfabeta: 2008

Suprapto, Suprapto. Pengantar Teori Komunikasi. Yogyakarta , Media Pressindo: 2006 
78 |Jurnal Dakwah dan Komunikasi, Vol. 3, No. 1, 2018

Tubbs, Stewart L. dan Sylvia Moss. Human Communication: Konteks-Konteks Komunikasi.diterjemabkan oleh Deddy Mulyana dan Gembirasari. Bandung, Remaja Rosdakarya: 2001

West, Richard dan Lynn H. Turner. Pengantar Teori Komunikasi: Analisis dan Aplikasi. Jakarta, Salemba Humanika: 2008

Wiryanto, Teori Komunikasi Massa. Jakarta, Grasindo: 2000

\section{Referensi Online:}

www.staincurup.ac.id 